\title{
Human Papillomavirus and Cervical Cancer - A Review
}

\author{
Pugalendhi P* and Uma S
}

Department of Biochemistry and Biotechnology, Annamalai University, India

Submission: August 14, 2018; Published: October 16, 2018

*Corresponding author: Pugalendhi P, Department of Biochemistry and Biotechnology, Faculty of Science Annamalai University, Annamalainagar - 608 002, Tamil Nadu, India, Tel: +91-4144-239141; Email: pugalau@gmail.com

\section{Abstract}

Cervical cancer used to be the leading cause of cancer death for women. Human Papillomavirus (HPV) infection is responsible for more than $90 \%$ cervical cancer. About $6.6 \%$ of women in Indian population are estimated to harbor cervical HPV infection. HPV 16 and 18 are accounting most prevalent type in cervical adenocarcinomas. In HPV life cycle, high-level amplification of the viral genome move outer layers of the epithelium are released to re-initiate infection, persistent infection leads to precancerous lesion. The numbers of cervical cancer cases and deaths have decreased significantly over the period with efficient diagnostic technique like Pap smear test. Development of sensitive technique for early detection of HPV infection and vaccination further reduce the incidence of cervical cancer.

Keywords: Cervical cancer; Human Papillomavirus infection; Pap smear test

Abbreviations: HPV: Human Papillomavirus; LCR: Long Control Region; SCC: Squamous Cell Carcinoma; LSIL: Low Grade Squamous Intraepithelial Lesion; HSIL: High Grade Intraepithelial Lesion; TLR: Toll Like Receptors; NK: Natural Killer

\section{Introduction}

Globally cervical cancer is the fourth most common cancer in women. Cervical cancer occurs due to neoplastic transformation of cells in the cervix i.e. lower part of the uterus. The worldwide incidence of cervical cancer, 5,10,000 new cases diagnosed every year and approximately 2,88,000 deaths [1]. In India, 1,32,000 new cases diagnosed and 74,000 death every year. The incidence is more common in women above the age of 30 years. Cervical cancer is almost always caused by Human Papilloma Virus (HPV) infection [2]. HPV infection is responsible for more than $90 \%$ cervical cancer causes and the other less important factors include smoking, weak immune system, birth control pills, and unsafe sex (contraceptives) [3]. 90\% of cervical cancer cases are squamous cell carcinomas and $10 \%$ are adenocarcinoma. About $6.6 \%$ of women in Indian population are estimated to harbor cervical HPV infection.

\section{Human Papilloma Virus (HPV)}

Figure 1: Human Papilloma Virus (HPV).


HPV are small (50 nm) double-stranded DNA viruses composed of a genome of 8kilobase pair, enclosed inside a nonenveloped capsid protein. The genome consists of three sets: (a) early genes (E1, E2, E4, E5, E6, E7) which regulate the vegetative and productive phase of viral life cycle: (b) late genes (L1, L2) which encode the capsid protein and (c) a non-coding regulatory region called Long Control Region (LCR) control the regulation of viral replication and transcription [4] (Figure 1).

\section{Types}

Approximately 200 different HPV types have been characterized, and the two most frequent high-risk HPV genotypes, HPV16 and HPV-18, according for 70\% of cases. HPV6 and HPV11 are common causes of genital warts and precancerous lesions [5]. The HPVs can be broadly grouped into cutaneous types and mucosal types based on tissue tropism. The cutaneous types are found in the general population and cause common warts with individuals are immunosuppressed. The mucosal HPVs are further classified into high-risk and low-risk types, based on their respective degree of association with cervical cancer. The most common lowrisk types are HPV 6 and 11, detected most often in benign genital warts. HPV 16, 18, 31, and 45 are predominant types found in cervical Squamous Cell Carcinoma (SCC), accounting for more than $90 \%$ of cases, with HPV 16 alone accounting for about half the cases worldwide [6]. HPV 18 is the most prevalent type in cervical adenocarcinomas (55\%), followed by HPV 16 (32\%) and HPV 45 (10\%). Epidemiological evidence suggests that infection with HPV is the greatest risk factor [7]. Its, role in the progression of the precursor lesions to cervical cancer is well established [8].

\section{Mechanism of HPV infection}

HPV infection normally does not integrate its DNA to host DNA. In high-risk HPV, DNA is often integrated into the human genome in cervical squamous cell carcinoma. It has been proposed that integration can be an early event associated with Low Grade Squamous Intraepithelial Lesion (LSIL) to High Grade Intraepithelial Lesion (HSIL) progression [9]. HPV can infect cells through damaged tissue. In the immune response, keratinocytes play an important role which can express Toll Like Receptors (TLR), participate in the innate immune response and recognize both endogenous and exogenous. In this process, TLRs are activated and can synthesize and release a variety of cytokines involved in immune regulation like IL-1, IL-6, IL-8, IL-10, TNF- $\alpha$ and IFN- $\beta$ to activate Natural Killer (NK) cells [10]. The NK-activating receptors affect the cytolytic functionality. It elicits a proinflammatory expression profile which promotes innate immunity. The initial inflammatory response leads to infiltration of immune cells such as neutrophils, macrophages and lymphocytes.

HPVs are exclusively epitheliotropic, and their replication is intimately linked to the differentiation process of the host cells. Normal squamous epithelial cells grow as stratified epithelium, with those in the basal layers dividing as stem cells of transient amplifying cells. After division, one of the daughter cells migrates upward and begins to undergo terminal differentiation while the other remains in the basal layer as a slow-cycling, self-renewing population. Productive papillomavirus infection begins when infectious daughter cells of the basal layer, probably through micro-wounds. The viral genome is maintained in these cells as a stable episome at low copy number, and that generate productive wart. The early HPV genes E1 and E2 support viral DNA replication and its segregation such that the infected cells can be maintained in the lesion for a long period. As infected daughter cells migrate towards the epithelial surface, viral late gene products are produced to initiate the vegetative phase of the HPV life cycle, resulting in the high-level amplification of the viral genome. In the outer layers of the epithelium, viral DNA is packaged into capsids and progeny virions are released to re-initiate infection, persistent infection rather than clearance of the virus linked to the development of precancerous lesion followed for invasion and metastasis [11].

\section{Diagnosis}

The important methods to diagnose HPV infection are

- Pap smear test-It is a screening test first describe by Papanicolaou and Traut. Apart from premalignant and malignant changes, viral infections like HPV infection and Herpes can also be detected. Positive test requires further confirmatory tests like colposcopy, cervical biopsy, and DNA tests like PCR.

- Colposcopy and acetic acid test- Colposcopy is the examination of the cervix, vagina, and in some instances the vulva after the application of acetic acid solution.

- $\quad$ Biopsy- Colposcopy allows tissue sampling (biopsy) that is targeted to the abnormal areas.

- DNA test (PCR, Southern Blot Hybridization, In Situ Hybridization) - Initial methods of HPV detection used were direct probe hybridization such as dot blot and Southern blot.

\section{Prevention}

The two novel and highly efficacious prevention methods are prophylactic HPV vaccination to control the early peak of infections and sensitive HPV-based screening to detect and treat the secondary peak of precancerous $[12,13]$.

\section{Conclusion}

This review has described the mechanism of HPV mediated carcinogenesis in human cells. A future challenge to this end is defining the research agenda for deciding on the optimal technology and intensity of screening to make cervical cancer a very rare disease while minimizing the possible harms.

\section{References}

1. Atlanta GA (2018) Cancer Facts \& Figures. American Cancer Society.

2. ICO Information Center on HPV and cancer (2014) Human papillomavirus and related disease in India (summary report 2014-08-22).

3. Cervical cancer: estimated incidence mortality and prevalence worldwide in 2012. Globocan 2012. 
4. Howley PM, Lowry DR (2007) Papillomaviruses. In: Knipe DM \& Howley PM (eds.), Fields virology. Lippincott, Williams and Wilkins, Pennsylvania, United States p. 2299-2354.

5. Stanley MA, Pett MR, Coleman N (2007) HPV: from infection to cancer. Biochem Soc Trans 35(Pt 6): 1456-1460.

6. Clifford GM, Smith JS, Aguado T, Franceschi S (2003) Comparison of HPV type distribution in high-grade cervical lesions and cervical cancer: a meta-analysis. Br J Cancer 89(1): 101-105.

7. Zielinski GD, Snijders PJ, Rozendaal L, Daalmeijer NF, Risse EK, et al (2003) The presence of high-risk HPV combined with specific p53 and p16INK4a expression patterns points to high-risk HPV as the main causative agent for adenocarcinoma in situ and adenocarcinoma of the cervix. J Pathol 201(4): 535-543.

8. Bosch FX, Lorincz A, Munoz N, Meijer CJ, Shah KV (2002) The causal relation between human papillomavirus and cervical cancer. J Clin Pathol 55(4): 244-265.

This work is licensed under Creative Commons Attribution 4.0 License

DOI: 10.19080/JTMP.2018.03.555617
9. Kulmala SM, Syrjanen SM, Gyllensten UB, Shabalova IP, Petrovichev N, et al. (2006) Early integration of high copy HPV16 detectable in women with normal and low-grade cervical cytology and histology. J Clin Pathol 59(5): 513-517.

10. Deligeoroglou E, Giannouli A, Athanasopoulos N, Karountzos V Vatopoulou A, et al. (2013) HPV Infection: Immunological Aspects and Their Utility in Future Therapy. Infect Dis Obstet Gynecol 540850.

11. Doorbar J (2005) The papillomavirus life cycle. J Clin Virol 32(Suppl 1): S7-S15.

12. Schiffman M, Doorbar J, Wentzensen N, de Sanjosé S, Fakhry C, et al. (2016) Carcinogenic human papillomavirus infection. Nat Rev Dis Primers 2: 16086.

13. Bosch FX, Robles C, Diaz M, Arbyn M, Baussano I, et al. (2016) HPVFASTER: Broadening the scope for prevention of HPV-related cancer Nat Rev Clin Oncol 13(2): 119-132.

\section{Your next submission with Juniper Publishers will reach you the below assets}

- Quality Editorial service

- Swift Peer Review

- Reprints availability

- E-prints Service

- Manuscript Podcast for convenient understanding

- Global attainment for your research

- Manuscript accessibility in different formats

( Pdf, E-pub, Full Text, Audio)

- Unceasing customer service

Track the below URL for one-step submission https://juniperpublishers.com/online-submission.php 